В.О. Фіщенко ${ }^{1}$, Л.О. Килимнюк ${ }^{1,}$ Л.І. Лайко ${ }^{1}$, В.М. Ковальчук ${ }^{2}$, О.П. Ренкас ${ }^{2}$

${ }^{1}$ Вінницький національний медичний університет імені М.І. Пирогова

${ }^{2}$ Національна медична академія післядипломної освіти імені П.Л. Шупика, Київ

\title{
Консервативна стимуляція остеогенезу при сповільненій консолідації переломів трубчастих кісток
}

Мета - оцінити ефективність застосування фокусної екстракорпоральної ударно-хвильової терапії (фЕУХТ) при сповільненій консолідації переломів трубчастих кісток. Об'єкт іметоди дослідження. Обстежено 25 пацієнтів зі сповільненою консолідацією переломів трубчастих кісток (середній вік - 40,24士16,55 року). Серед обстежених виділено досліджувану - 13(52,0\%) та контрольну групу - 12(48,0\%) пацієнтів. Учасникам досліджуваної групи проводили 5-7 процедур фЕУХТ з інтервалом 5-6 днів. Основним методом лікування пацієнтів контрольної групи був хірургічний. Для оцінки результатів лікування використовували шкалу Neer - Grantham - Shelton в модифікації D. Cherkes-Zade та співавторів (2003). Результати. У результаті застосування фЕУХТ зрощення переломів вдалося досягнути у 11 (84,6\%) пацієнтів досліджуваної групи, у 3 (23, 1\%) виявили ознаки невірної консолідації уламків, які не погіршували функціональної здатності кінцівки. Достовірної різниці між віддаленими результатами лікування у пацієнтів обох груп не встановлено за показниками больового синдрому $(p=0,34)$, наявності анатомічного вкорочення $(p=0,39)$, обмеження обсягу рухів $(p=0,37)$, рентгенологічними змінами $(p=0,25)$, працездатністю $(p=0,27)$ та сумарними результатами $(p=0,66)$. Висновки. Відсутність достовірної різниці результатів хірургічного лікування та застосування фЕУХТ дозволяють рекомендувати ї̈ як альтернативний метод лікування при сповільненій консолідації.

Ключові слова: сповільнена консолідація, порушення зрощення переломів, фокусна екстракорпоральна ударнохвильова терапія, стимуляція репаративного остеогенезу, переломи трубчастих кісток, репаративний остеогенез.

\section{Вступ}

Проблема лікування при розладах репаративного остеогенезу залишається актуальною для сучасної травматології та ортопедії. Сповільнення консолідації кісткових уламків при переломах трубчастих кісток реєструють у 15-50\% випадків (Іванов О.М. та ін., 2015). Розлади репаративного остеогенезу пов'язані з подовженням періоду іммобілізації пацієнта та підвищенням ризику вторинних ускладнень. Частка незадовільних результатів лікування при порушеннях зрощення переломів сягає 33\% (Попсуйшапка А.К. та співавт., 2013). Стандартом лікування при порушеннях зрощення протягом тривалого часу є хірургічна стабілізація кісткових фрагментів методиками внутрішнього чи зовнішнього остеосинтезу з використанням кісткових аутотрансплантатів як додаткових стимуляторів остеогенезу (Haffner N. et al., 2016). Однак використання цієї методики часто супроводжується формуванням тривалого больового синдрому та парестезіями в ділянці пошкодження, незрощенням та інфекційними ускладненнями (Cheng J.H., Wang C.J., 2015; Schaden W. et al., 2015). Низька результативність тривалого лікування пацієнтів з розладами репаративного остеогенезу, високі рівні захворюваності та інвалідності свідчать про актуальність проблеми пошуку ефективних методів консервативної стимуляції репаративного остеогенезу та необхідність її подальшого вивчення.

Мета дослідження - оцінити ефективність застосування фокусної екстракорпоральної ударно-хвильової терапії (фЕУХТ) при сповільненій консолідації переломів трубчастих кісток.

\section{Об'єкт і методи дослідження}

Проаналізовано результати лікування 25 пацієнтів (15 чоловіків та 10 жінок, середній вік становив $40,24 \pm 16,55$ року) зі сповільненою консолідацією переломів трубчастих кісток, які проходили лікування на базі кафедри травматології та ортопедії Вінницького національного медичного університету імені М.І. Пирогова в період 2013-2017рр. Переважну більшість пацієнтів $21(84,0 \%)-$ становили особи працездатного віку. Виокремлено досліджувану - 13 (52,0\%) та контрольну групу - 12 (48,0\%) пацієнтів. Пацієнтам досліджуваної групи з метою консервативної стимуляції репаративного остеогенезу проводили 5-7 процедур
ФЕУХТ з урахуванням анатомічної локалізації пошкодження, які виконували з інтервалом 5-6 днів. Частота ударів відповідала 10-15 Гц, робочий тиск - 3,5-4,0 бар, використовували головку R 15. Сумарна кількість ударів на ділянку пошкодження за одну процедуру становила 3500-4000 ударів. Для проведення фЕУХТ використовували апарат фірми «Swiss DolorClast» (Швейцарія).

Результати лікування оцінено за допомогою шкали Neer Grantham - Shelton (1967) в модифікації D. Cherkes-Zade та співавторів (2003). Оцінку результатів проводили при первинному зверненні та після закінчення курсу лікування. Розподіл досліджуваної вибірки згідно з тестом Колмогорова - Смирнова достовірно відрізнявся від нормального $(p<0,05)$. Для оцінки вірогідності безпомилкового прогнозу при порівнянні двох незалежних груп використовували непараметричний U-тест Манна Уїтні. Отримані результати наведено у вигляді середнього арифметичного \pm середнього квадратичного відхилення (M $\pm \mathrm{SD})$. Вірогідність безпомилкового прогнозу встановлювали при $\mathrm{p} \leqslant 0,05$. Для статистичної обробки матеріалів використовували програму «Statistica 10».

\section{Результати та їх обговорення}

У пацієнтів зі сповільненою консолідацією сумарні результати при первинному зверненні оцінювали як задовільні, які спостерігали у $11(84,6 \%)$ пацієнтів досліджуваної та 10 (83,3\%) - контрольної групи. Незадовільні результати виявлено у $2(15,4 \%)$ пацієнтів досліджуваної і у $2(16,7 \%)-$ контрольної групи. При порівнянні первинних результатів достовірної різниці між групами за всіма досліджуваними параметрами не встановлено (табл. 1).

Таблиця 1. Результати лікування, встановлені при первинному зверненні пацієнтів зі сповільненою консолідацією переломів

\begin{tabular}{lccc}
\hline \multicolumn{1}{c}{ Характеристика } & $\begin{array}{c}\text { Досліджувана } \\
\text { група, балів }\end{array}$ & $\begin{array}{c}\text { Контрольна } \\
\text { група, балів }\end{array}$ & $\mathbf{p}$ \\
\hline Сумарні результати & $44,23 \pm 6,72$ & $42,08 \pm 5,42$ & 0,34 \\
Больовий синдром & $5,77 \pm 4,49$ & $5,42 \pm 3,34$ & 0,77 \\
Анатомічне вкорочення & $10,38 \pm 1,39$ & $9,58 \pm 1,44$ & 0,18 \\
Обмеження обсягу рухів & $8,46 \pm 2,40$ & $7,92 \pm 2,57$ & 0,60 \\
Рентгенологічні показники & $10 \pm 0$ & $10 \pm 0$ & 1,0 \\
Працездатність & $9,62 \pm 1,39$ & $9,58 \pm 1,44$ & 0,98 \\
\hline
\end{tabular}


Больовий синдром відзначали у всіх пацієнтів досліджуваної та контрольної груп. Помірний біль, що потребував застосування анальгезивних засобів, виявлено у $6(46,1 \%)$ пацієнтів досліджуваної та у $3(25,0 \%)$ - контрольної групи. У $3(23,1 \%)$ пацієнтів досліджуваної групи для зниження інтенсивності больового синдрому був необхідний відпочинок, подібний характер болю спостерігали у 7 (58,3\%) пацієнтів контрольної групи. Больовий синдром, що потребував застосування анальгетиків, відзначали у $4(30,8 \%)$ пацієнтів досліджуваної та у $2(16,7 \%)$ контрольної групи. Переважна більшість пацієнтів досліджуваної групи - 12 (92,3\%) та 11 (91,7\%) контрольної групи мали ознаки анатомічного вкорочення до $2 \mathrm{~cm}$. Відсутність анатомічного вкорочення встановлено у $1(7,7 \%)$ пацієнта досліджуваної групи. У $1(8,3 \%)$ пацієнта контрольної групи виявлено вкорочення $>2$ см. Обмеження обсягу рухів встановлено у всіх пацієнтів обох груп. У більшості пацієнтів обох груп - $9(69,2 \%)$ та 7 (58,3\%) відповідно - була наявна помірна контрактура, що не обмежувала функції кінцівки. У всіх пацієнтів обох груп рентгенологічно встановлено ознаки сповільнення консолідації. Переважну більшість пацієнтів обох груп - 12 (92,3\%) та 11 (91,7\%) відповідно - переведено на легші умови праці. У 1 (7,7\%) пацієнта досліджуваної та у $1(8,3 \%)$ - контрольної групи була наявна III група інвалідності.

У віддалений період хороші результати відзначено у 7 (53,8\%), задовільні - у $6(46,1 \%)$ пацієнтів досліджуваної групи. Серед пацієнтів контрольної групи хороших результатів досягнуто у $6(50,0 \%)$, задовільних - у 6 (50,0\%). Незадовільних результатів лікування у пацієнтів обох груп не було. При порівнянні віддалених результатів лікування у пацієнтів обох груп достовірної різниці між досліджуваними показниками не встановлено (табл. 2).

Таблиця 2. Порівняльна характеристика віддалених результатів лікування пацієнтів зі сповільненою консолідацією переломів

\begin{tabular}{lccc}
\multicolumn{1}{c}{ Характеристика } & $\begin{array}{c}\text { Досліджувана } \\
\text { група, балів }\end{array}$ & $\begin{array}{c}\text { Контрольна } \\
\text { група, балів }\end{array}$ & $\mathbf{p}$ \\
\hline Сумарні результати & $61,15 \pm 15,3$ & $62,08 \pm 9,64$ & 0,66 \\
Больовий синдром & $13,08 \pm 3,25$ & $12,08 \pm 2,57$ & 0,34 \\
Анатомічне вкорочення & $12,69 \pm 2,59$ & $11,67 \pm 2,46$ & 0,40 \\
Обмеження обсягу рухів & $11,54 \pm 2,40$ & $12,5 \pm 3,37$ & 0,37 \\
Рентгенологічні показники & $11,15 \pm 5,46$ & $13,75 \pm 4,33$ & 0,25 \\
Працездатність & $12,69 \pm 3,3$ & $11,25 \pm 3,11$ & 0,28 \\
\hline
\end{tabular}

У віддалений післяопераційний період у переважної більшості пацієнтів досліджуваної групи - $9(69,2 \%)$ - відзначали відсутність больового синдрому, у $3(23,1 \%)$ - біль помірного характеру, що не потребував застосування анальгетиків, у 1 (7,69\%) пацієнта біль зникав після відпочинку. У переважної більшості пацієнтів групи контролю - 7 (58,3\%) був наявний біль помірного характеру, який проходив самостійно без застосування анальгетиків, і у $5(41,7 \%)$ больовий синдром був відсутній. Відсутність анатомічного укорочення сегмента зареєстровано у переважної більшості пацієнтів досліджуваної групи - 7 (53,8\%) та у 4 (33,3\%) осіб групи контролю. У більшості хворих контрольної групи - $8(66,7 \%)$ та $6(46,1 \%)$ групи контролю було наявне вкорочення до 2 см; вкорочення $\geqslant 2-4$ см не зареєстровано у жодного пацієнта обох груп. Рухи в повному обсязі були збережені у 4 (30,8\%) пацієнтів досліджуваної та у 7 (58,3\%) - контрольної групи. Переважна більшість пацієнтів досліджуваної групи - $9(69,2 \%)$ та $4(33,3 \%)$ групи контролю мали помірну контрактуру, що не впливала на функцію кінцівки. Виражену контрактуру, що обмежувала рухи, встановлено у 1 (8,3\%) пацієнта групи контролю. Рентгенологічні ознаки зрощення відзначено у $8(61,5 \%)$ пацієнтів досліджуваної та у $11(91,7 \%)$ - контрольної групи. У $3(23,1 \%)$ пацієнтів досліджуваної групи був наявний невірно консолідований перелом, ще у $1(7,7 \%)$ - ознаки сповільнення консолідації. Наявність хибного суглоба виявили у $1(7,7 \%)$ пацієнта досліджуваної та у 1 (8,3\%) - контрольної групи.

Непрацездатних осіб серед обстежених не було. Більшість осіб досліджуваної групи - $8(61,5 \%)$ повернулися на попередне місце роботи та лише 4 (33,3\%) особи групи контролю. Переведені на легші умови праці $4(30,8 \%)$ пацієнти із досліджуваної та 7 (58,3\%) - контрольної групи. III група інвалідності була наявна у $1(7,7 \%)$ особи досліджуваної та у 1 (8,3\%) - контрольної групи.
При порівнянні результатів лікування, встановлених при первинному звернені та у віддалений період у пацієнтів контрольної групи, встановлено достовірну різницю у показниках болю $(p=0,00019)$, анатомічного вкорочення $(p=0,025)$, обмеження обсягу рухів $(p=0,0029)$ та рентгенологічних показниках $(p=0,0001)$ (табл. 3). Крім того, сумарні результати лікування у віддалений період були достовірно кращими порівняно з первинними даними $(p=0,00018)$.

Таблиця 3. Порівняльна характеристика первинних результатів лікування та результатів віддаленого періоду пацієнтів контрольної групи

\begin{tabular}{lccc}
\hline \multicolumn{1}{c}{ Характеристика } & $\begin{array}{c}\text { Первинні } \\
\text { результати, } \\
\text { балів }\end{array}$ & $\begin{array}{c}\text { Віддалені } \\
\text { результати, } \\
\text { балів }\end{array}$ & $\mathbf{p}$ \\
\hline Сумарні результати & $42,08 \pm 5,42$ & $62,08 \pm 9,64$ & $0,0002^{*}$ \\
Больовий синдром & $5,42 \pm 3,34$ & $12,08 \pm 2,57$ & $0,0002^{*}$ \\
Анатомічне вкорочення & $9,58 \pm 1,44$ & $11,67 \pm 2,46$ & $0,03^{*}$ \\
Обмеження обсягу рухів & $7,92 \pm 2,57$ & $12,5 \pm 3,37$ & $0,003^{*}$ \\
Рентгенологічні показники & $10 \pm 0$ & $13,75 \pm 4,33$ & $0,0001^{*}$ \\
Працездатність & $9,58 \pm 1,44$ & $11,25 \pm 3,11$ & 0,10 \\
\hline
\end{tabular}

У табл. 3 і 4: *достовірна різниця між показниками при $p \leqslant 0,05$.

При порівнянні первинних та віддалених результатів лікування пацієнтів досліджуваної групи встановлено достовірно кращі результати лікування у віддалений період за показниками вираженості больового синдрому ( $p=0,00029)$, наявності анатомічного вкорочення $(p=0,014)$, обмеження обсягу рухів $(p=0,006)$ та працездатності ( $p=0,0046)$. Крім того, у пацієнтів досліджуваної групи спостерігали достовірно кращі сумарні результати лікування порівняно з пацієнтами контрольної групи $(p=0,007)$ (табл. 4).

Таблиця 4. Порівняльна характеристика первинних результатів лікування та результатів віддаленого періоду пацієнтів досліджуваної групи

\begin{tabular}{lccc}
\hline \multicolumn{1}{c}{ Характеристика } & $\begin{array}{c}\text { Первинні } \\
\text { результати, } \\
\text { балів }\end{array}$ & $\begin{array}{c}\text { Віддалені } \\
\text { результати, } \\
\text { балів }\end{array}$ & $\mathbf{p}$ \\
\hline Сумарні результати & $44,23 \pm 6,72$ & $61,15 \pm 15,3$ & $0,007^{*}$ \\
Больовий синдром & $5,77 \pm 4,49$ & $13,08 \pm 3,25$ & $0,0003^{*}$ \\
Анатомічне вкорочення & $10,38 \pm 1,39$ & $12,69 \pm 2,59$ & $0,014^{*}$ \\
Обмеження обсягу рухів & $8,46 \pm 2,40$ & $11,54 \pm 2,40$ & $0,006^{*}$ \\
Рентгенологічні показники & $10 \pm 0$ & $11,15 \pm 5,46$ & 0,15 \\
Працездатність & $9,62 \pm 1,39$ & $12,69 \pm 3,3$ & $0,005^{*}$ \\
\hline
\end{tabular}

\section{Висновки}

У результаті застосування фЕУХТ зрощення переломів вдалося досягти у $11(84,6 \%)$ пацієнтів досліджуваної групи. У $3(23,1 \%)$ пацієнтів досліджуваної групи спостерігали ознаки невірної консолідації уламків, які не погіршували функціональної здатності кінцівки та не потребували подальшої ортопедичної реконструкції. Ефективність хірургічного лікування при сповільненій консолідації становила 91,7\%. Таким чином, фЕУХТ $€$ альтернативним варіантом лікування при сповільненій консолідації уламків, її ефективність достовірно не відрізняється від результатів традиційного стабільно-функціонального остеосинтезу. Оскільки фЕУХТ є консервативним методом стимуляції репаративного остеогенезу, вона позбавлена усіх ризиків хірургічного втручання. Крім того, її перевагами $€$ широкий спектр показань до використання та раннє відновлення працездатності.

\section{Список використаної літератури}

Іванов О.М., Березка М.І., Литовченко В.О., Гарячий Є.В. (2015) Результати використання репаративної методики лікування дисрегенерацій кісткової тканини. Scientific Journal «ScienceRise», 10/3(15): 5-11.

Попсуйшапка А.К., Ужигова О.Е., Литвишко В.А. (2013) Частота несращения и замедленного сращения отломков при изолированных диафизарных переломах длинных костей конечностей. Ортопедия, травматология и протезирование, 1: 39-43.

Cheng J.H., Wang C.J. (2015) Biological mechanism of shockwave in bone. Int. J. Surg., 24(Pt. B): 143-146

Haffner N., Antonic V., Smolen D. et al. (2016) Extracorporeal shockwave therapy (ESWT) ameliorates healing of tibial fracture non-union unresponsive to conventional therapy. Injury, 47(7): 1506-1513.

Schaden W., Mittermayr R., Haffner N. et al. (2015) Extracorporeal shockwave therapy (ESWT)-First choice treatment of fracture non-unions? Int. J. Surg., 24(Pt. B): 179-183. 


\section{Консервативная стимуляция остеогенеза при замедленной консолидации переломов трубчатых костей \\ В.А. Фищенко, Л.А. Килимнюк, Л.И. Лайко, В.Н. Ковальчук, Е.П. Ренкас}

Резюме. Цель - оценить эффективность применения фокусной экстракорпоральной ударно-волновой терапии (фЭУВТ) при замедленной консолидации переломов трубчатых костей. Объект и методы исследования. Обследовано 25 пациентов с замедленной консолидацией переломов трубчатых костей (средний возраст - 40,24士16,55 года). Среди обследованных выделена исследуемая - 13(52,0\%) и контрольна группа - 12(48,0\%) пациентов. Участникам исследуемой группы проводили 5-7 процедур фЭУВТ с интервалом 5-6 дней. Основным методом лечения пациентов контрольной группы был хирургический. Для оценки результатов лечения использовали шкалу Neer Grantham - Shelton в модификации D. Cherkes-Zade и соавторов (2003). Результаты. В результате использования фЭУВТ сращения переломов удалось достичь у $11(84,6 \%)$ пациентов исследуемой группы, у $3(23,1 \%)$ отмечены признаки неверной консолидации, которые не ухудшили функциональной способности конечности. Достоверной разницы между отдаленными результатами лечения у пациентов обеих групп не установлено по показателям болевого синдрома $(p=0,34)$, наличия анатомического укорочения $(p=0,39)$, ограничения объема движений $(p=0,37)$ рентгенологическим изменениям $(p=0,25)$, трудоспособности $(p=0,27)$ и суммарным результатам $(p=0,66)$. Выводы. Отсутствие достоверной разницы между результатами хирургического лечения и использованием фЭУВТ позволяет рекомендовать ее в качестве альтернативного метода лечения при замедленной консолидации.

Ключевые слова: замедленная консолидация, нарушения сращения переломов, фокусная экстракорпоральная ударно-волновая терапия стимуляция репаративного остеогенеза, переломы трубчатыхкостей, репаративный остеогенез.

\section{Nonoperative stimulation of osteogenesis for delayed union of fractures of tubular bones}

\section{O. Fishchenko, L. O. Kylymniuk, L.I. Laiko, V.M. Kovalchuk, O.P. Renkas}

Summary. Aim - to assess the efficiency of the using focal extracorporeal shockwave therapy (fESWT) for delayed union of fractures of tubular bones. Object and methods. 25 patients with delayed union of fractures of tubular bones were examined (the average age was $40.24 \pm 16.55$ years). Among the examined patients were formed investigated group, which consists of $13(52.0 \%)$ patients and control group included 12(48.0\%). Patients of the investigated group were given 5-7 procedures of fESWT with an interval of 5-6 days. The main method of treating of patients of the control group was surgical. Neer - Grantham - Shelton scale with modification D. CherkesZade et al. (2003) was used to evaluate the results of the treatment. Results. As a result, fracture healing was founded in 11 (84.6\%) patients of the investigated group, 3(23.1\%) showed signs of malunion, that did not worsen the functional capacity of the limb. There was no significant difference between the long-term results in patients of both groups for indicators of pain syndrome $(p=0.34)$, presence of anatomical shortening $(p=0.39)$, limitation of movement ( $p=0.37)$, radiologic changes $(p=0.25)$, work capacity $(p=0.27)$ and total results $(p=0.66)$. Conclusions. The absence of significant difference in the results of surgical treatment and the using fESWT allows recommending it as an alternative treatment for delayed union.

Key words: delayed union, fracture healing complications, focal extracorporal shockwave therapy, stimulation of reparative osteogenesis, fracture of tubular bones, reparative osteogenesis.

\section{Адреса для листування: \\ Килимнюк Любов Олександрівна \\ 21000 , Вінниця, вул. Пирогова, 56 \\ Вінницький національний медичний університет імені М.І. Пирогова, кафедра травматології та ортопедії \\ E-mail: kylymniuk@gmail.com}

Одержано 12.03.2018 